\title{
The unplanned and unequal expansion of Dentistry courses in Brazil from 1856 to 2020
}

\author{
Maria Celeste MORITA(a) \\ Mário URIARTE NETO(a) \\ Vania Regina Camargo \\ FONTANELLA(b) $^{(b}$ \\ Ana Estela HADDAD ${ }^{(c)}$ iD \\ (a) Associação Brasileira de Ensino \\ Odontológico - ABENO, FOUSP/ABENO \\ Station of the Observatory of Human \\ Resources in Health Network, Porto Alegre, \\ RS, Brazil. \\ (b) Universidade Federal do Rio Grande do Sul \\ - UFRGS, School of Dentistry, Department \\ of Surgery and Orthopedics, Porto Alegre, \\ RS, Brazil. \\ (c) Universidade de São Paulo - USP, School of \\ Dentistry, Department of Orthodontics and \\ Pediatric Dentistry, São Paulo, SP, Brazil.
}

Declaration of Interests: The authors certify that they have no commercial or associative interest that represents a conflict of interest in connection with the manuscript.

Corresponding Author:

Ana Estela Haddad

E-mail: aehaddad@usp.br

hitps://doi.org/10.1590/1807-3107bor-2021.vol35.0009

Submitted: May 18. 2020

Accepted for publication: July 27, 2020

Last revision: August 19, 2020

\begin{abstract}
This study analyzed the consequences of the disordered expansion of Dentistry courses on the distribution of professionals, the job market, and limitations of the National System of Higher Education Assessment (SINAES) developed as a guarantee of education quality. This observational, descriptive, and analytical study used secondary data from several official databases. The number of courses was obtained from the e-MEC registry. From the Higher Education Census, the study collected historical series of courses offered, number of candidates per open seat, number of individuals who initiated and completed the course, and information about professors in the public and private schools. The reports related to Dentistry courses from the National Health Council were also analyzed. The performance of undergraduate students was assessed from synthesis reports of Enade from 2004 to 2016. The number of dentists and their regional distribution was based on the Federal Dental Council, and Brazilian population and gross domestic product were collected from the Brazilian Institute of Geography and Statistics. Dentistry courses in Brazil grew exponentially from 1856 to 2020; among the 544 authorized courses, 82 currently have not yet started their activities. The fast expansion of courses in Brazil has worsened the regional asymmetries in the supply of dentist, and the SINAES has not been able to fully assure the quality of Dentistry courses. Brazilian dentistry, which has increased its scientific and technological development since the 19th century, with outstanding intellectual production, is at risk of a collapse due to a plethora of dentists.
\end{abstract}

Keywords: Education, Dental; Dentistry; Health Workforce.

\section{Introduction}

The formal teaching of Dentistry in Brazil was initiated in the $19^{\text {th }}$ century, and in the initial stages its development was related to the expansion of Medicine courses. Historical data reveal that, until the end of the $19^{\text {th }}$ century, there were only three Dentistry courses in the country, in the cities of Rio de Janeiro, Salvador, and Porto Alegre. ${ }^{1}$ According to the electronic system of the Ministry of Education (e-MEC), the first Dentistry School was established in the Federal University 
of Rio de Janeiro (1856), followed by the Federal University of Bahia (1879), and Federal University of Rio Grande do Sul (1898). ${ }^{2}$

Until the middle of the $20^{\text {th }}$ century, after a movement for expanding higher education in Brazil towards the countryside, 24 courses were operating, distributed in all the Brazilian geographic regions, mostly in public institutions, except for some community or confessional institutions. However, despite such movement, there was an imbalance in the regional distribution at that time, with $50 \%$ of courses in the Southeastern region of the country. ${ }^{2}$

The onset of a more intensive expansion of courses occurred with the promulgation of the National Education Guidelines and Framework Law (LDB) in $1961 .{ }^{3}$ At that time, the Brazilian Association of Dental Education (ABENO) expressed concern that the expansion of Dentistry teaching should consider the regional social needs, and that adequate conditions of infrastructure and staff should be respected. The educational policy linked to the LDB of 1961, promoting the expansion of educational opportunities, provided legal and financial support for the private sector in the field of education, which explains the greater expansion of the private school network. ${ }^{4}$

The Brazilian University Renewal, a movement that started in 1968, added a new driving element for the expansion of Dentistry courses, namely the opening of higher education by for-profit private institutions, by relaxing the traditional standard of higher education based on the inseparable triad teaching-research-public outreach, allowing the offer of teaching alone, which reformatted the sector and opened the education market to institutions with a business profile. ${ }^{5}$ The prospect of offering a course with the possibility of attracting undergraduate students due to its social prestige has led Dentistry education to be seen as a promising business. The triggered expansion led to a four-fold increase in the number of Brazilian Dentistry courses until 1996, when there were 104 courses, 60 of which in private institutions. ${ }^{2}$

This study aimed to analyze the consequences of the disordered education growth on the distribution of professionals in the job market and professional status, as well as the limitations of evaluation mechanisms adopted by the National System of Higher Education Assessment (SINAES) ${ }^{6}$ designed to assure the quality of education.

\section{Methodology}

This observational, descriptive, and analytical study was conducted on secondary data from several official databases: the SINAES $^{6}$ instruments, the Technical Chamber of Human Resources of the National Health Council, ${ }^{7}$ the Federal Dental Council, ${ }^{8}$ and the Brazilian Institute of Geography and Statistics (IBGE). ${ }^{9,10}$

The SINAES ${ }^{6}$ is a complex system that consists of complementary instruments: self-assessment and external evaluation of Higher Education Institutions (IES), the National Assessment of Student Achievement (Enade), the evaluation of undergraduate courses, which considers three dimensions ("Pedagogical/ didactic Organization", "Faculty Members" including the percentage of Ph.D. and M.Sc. - and "Infrastructure"), and data instruments as the census and registry.

From the Higher Education Census (CES), ${ }_{1}^{11}$ the historical series was obtained from 1991 to 2018 and included the number of courses, seats offered, number of candidates per seat, and number of individuals who initiated and completed the course. CES data are released at the end of each calendar year; however, the information corresponds to the year of collection plus the period required to combine the outcomes, leading to a gap of approximately one year between the published year and the current year. To allow a more accurate and updated analysis of the number of Dentistry courses, the e-MEC system ${ }^{2}$ was also surveyed in March 2020, which is continuously updated and provides a simplified report presenting the number of courses, date of onset of activities, and seats offered. This database includes authorized courses, regardless of the onset of their activities, allowing assessment of the future potential projection of the number of courses in operation.

The analyses related to performance was done with data from Enade reports ${ }^{12}$ for the years 2004, 2007, 2010, 2013, and 2016. The Enade is an exam applied every three years to all last-term Dentistry 
undergraduate students in the country and results in a standardized score ranging from 1 to 5 .

Raw grades for Enade, pedagogical/didactic organization, faculty members' academic titles, and infrastructure, considering the public and private categories, were collected from the evaluation of undergraduate courses report for the year 2016.13

The number of dentists, as well as their regional distribution, were obtained from the database of the Federal Dental Council. ${ }^{8}$ Population and gross domestic product (GDP) estimates per Brazilian regions were obtained in the IBGE website.,10

The study also included the reports of the National Health Council (supported by Decree N. 9235/2017), ${ }^{7}$ issued from February 2018 to March 2020, on the authorization, recognition, and renewal of recognition of Dentistry courses.

\section{RESULTS}

Dentistry courses in Brazil presented an exponential growth from 1856 to 2020 (Figure 1). Currently, there are 544 authorized courses in the country, among which 82 have not yet initiated their activities. This expansion of courses occurred at different ratios over the study period. During the first hundred years, there was a mean increase of 0.8 courses/year. In the next two decades (from 1991 to 2010), there was an increase of 119 courses, with a mean increase of 6 courses/year. In the five subsequent years, from 2011 to 2015, there was a further increase of 40 courses, which corresponded to an expansion of 8 courses/year. A marked acceleration was observed after 2015, when there was an increase of 303 courses over a period of only five years, with 60.6 new courses/year.

Analysis of the entire historical series revealed an important change in the administrative category of the IES, which was observed after the 90s, since when the higher education in Brazil, including Dentistry, has been mostly offered by private institutions. ${ }^{5}$ According to the CES of 2018, nearly $80 \%$ of courses in the country were offered by private IES. Considering the number of seats offered every year, from the total of $34,806,29,933$ (86\%) were offered by private IES (Figure 2). According to the e-MEC system, a total of 73,291 seats were authorized for 2020. Most of the new courses and seats opened in the last three decades in Brazil are from private institutions. A slight exception was observed by

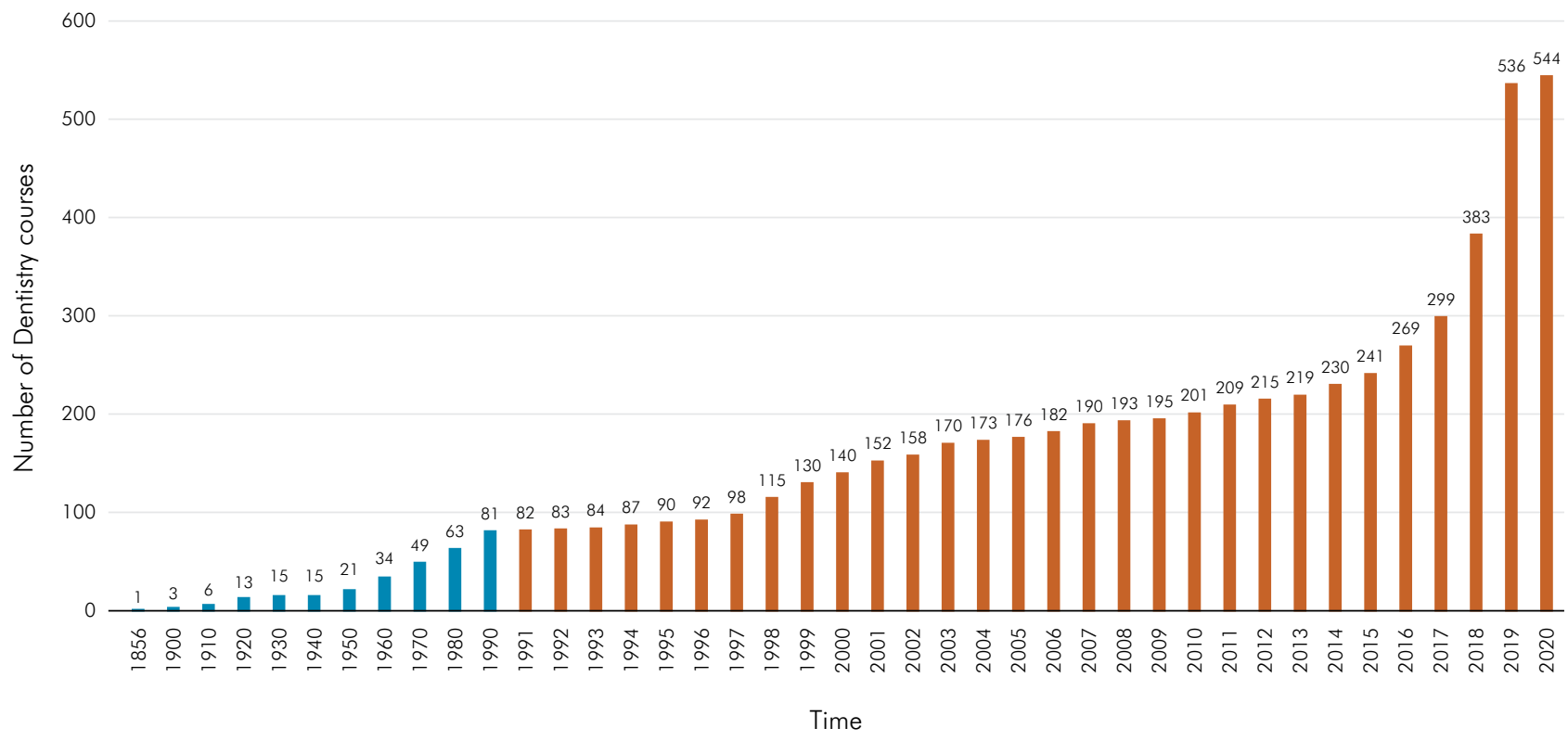

Figure 1. Expansion of the number of Dentistry courses in Brazil from $1900(n=3)$ to $2020(n=544)$ by decades (blue) and by year (orange), obtained from e-MEC² and CES.11 


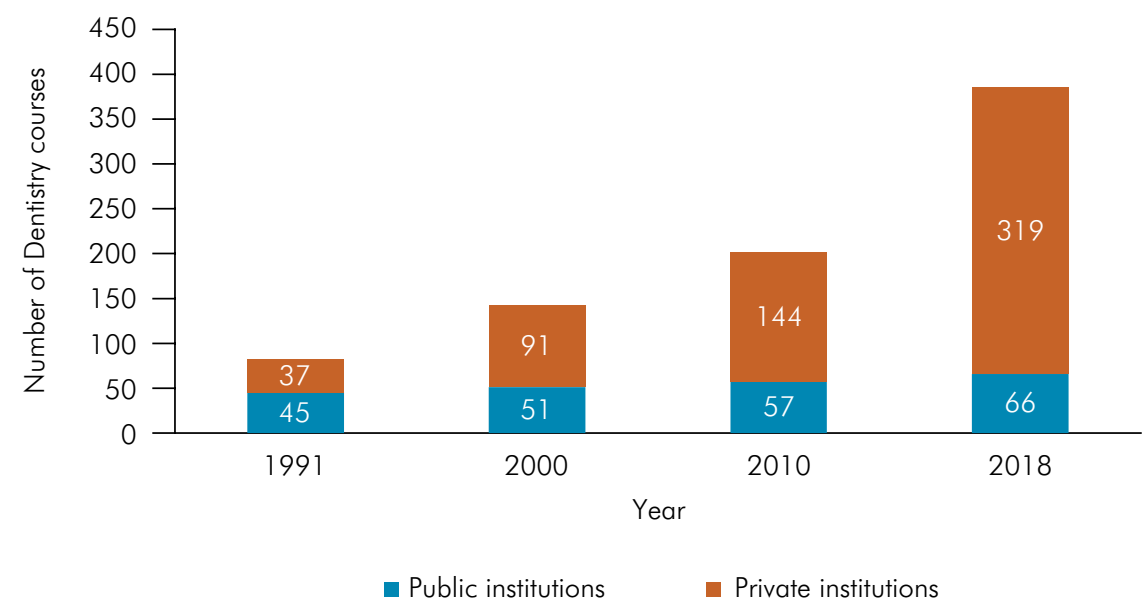

Figure 2. Juridical nature of Dentistry courses in Brazil from 1991 ( $n=82)$ to 2018 ( $n=385)$, obtained from CES. ${ }^{11}$

the establishment of new courses and seats in state institutions between 1991 and 2010, and in federal IES thanks to the aid provided by the Program of Support for the Restructuring and Expansion of Federal Universities (Reuni) ${ }^{14}$ after 2007.

The occupation of seats was not uniform and, even though the candidates/seat ratio has decreased in public IES with the advent of private institutions, from 2010 to 2018 this ratio was 19:1 in public institutions and 3:1 in private institutions, in average. It should be observed that many private IES are operating with an increasing number of unoccupied seats. The total number of unoccupied seats in Brazilian Dentistry courses was 6,069 in 2014 and increased to 27,553 in $2018,97 \%$ of which from private IES and $3 \%$ from public IES.

The number of Dentistry courses in Brazil presented a five-fold increase over a 28 -year period, from 1991 to 2020. From 2011 to 2018, the number of seats offered increased from 20,861 to 67,761 , and the number of undergraduate students who completed the course has doubled, from 9,637 to 18,530 .

Despite a slight improvement in the regional distribution of courses in the country (Figure 3), the concentration in the Southeast region, the richest one, remains until the present day, even after the exponential increase of courses observed in the study period. The slight improvement is observed in a period when, among the measures jointly adopted by the Ministries of Health and Education, the need
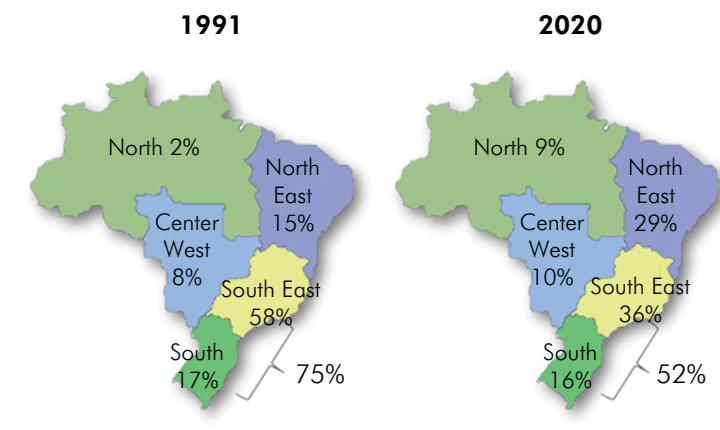

Figure 3. Distribution of Dentistry courses per Brazilian geographic region in 1991 ( $n=82)$ and 2020 ( $n=544)$, obtained from e-MEC ${ }^{2}$ and CES. ${ }^{11}$

of a report by the National Health Council was included in the SINAES. The assessment for such report considers the social relevance, need of new professionals, and resources available in the public health network of the Brazilian Public Health System (SUS) of the city where the creation of a new course is intended..$^{15}$

Even considering that the Brazilian population is not equally distributed among regions, ${ }^{9}$ the ratio of Dentistry courses and dental professionals per inhabitant is very unbalanced across the country, since both are similar to the distribution of the Brazilian GDP $^{10}$ (Figure 4).

The performance of Dentistry undergraduate students from public IES was better than those from 
private IES (Figure 5). In the 2016 Enade, most results of public IES scored 4 and 5 , while most outcomes of private institutions scored 3 or less.

Overall, Dentistry undergraduate students in Brazil are among those who achieve the best performance in health sciences concerning the specific knowledge of their education. It should be emphasized that, regarding the mean performance, the results for private and public IES is quite similar, despite differences in the internal distribution (Figure 6).

Analyzing the aspects evaluated by the SINAES, among the four factors that may explain the difference between institutions with a score of 5 (very good) and institutions with a score of 1 (unsatisfactory), the results highlight the higher

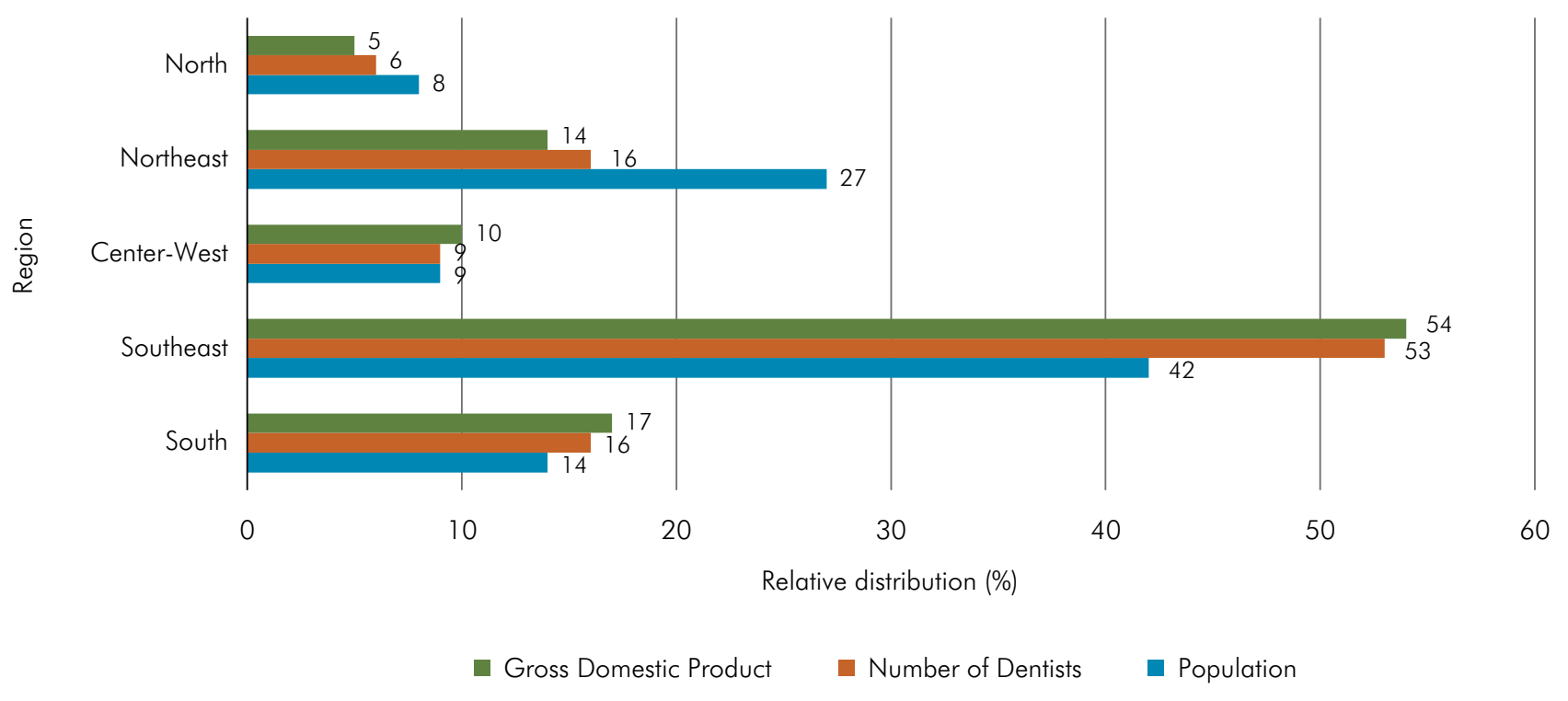

Figure 4. Relative distribution of dentists, population, and gross domestic product in the Brazilian geographic regions, obtained from CFO, ${ }^{8} \mathrm{BGGE}, 9$ and IBGE. ${ }^{10}$

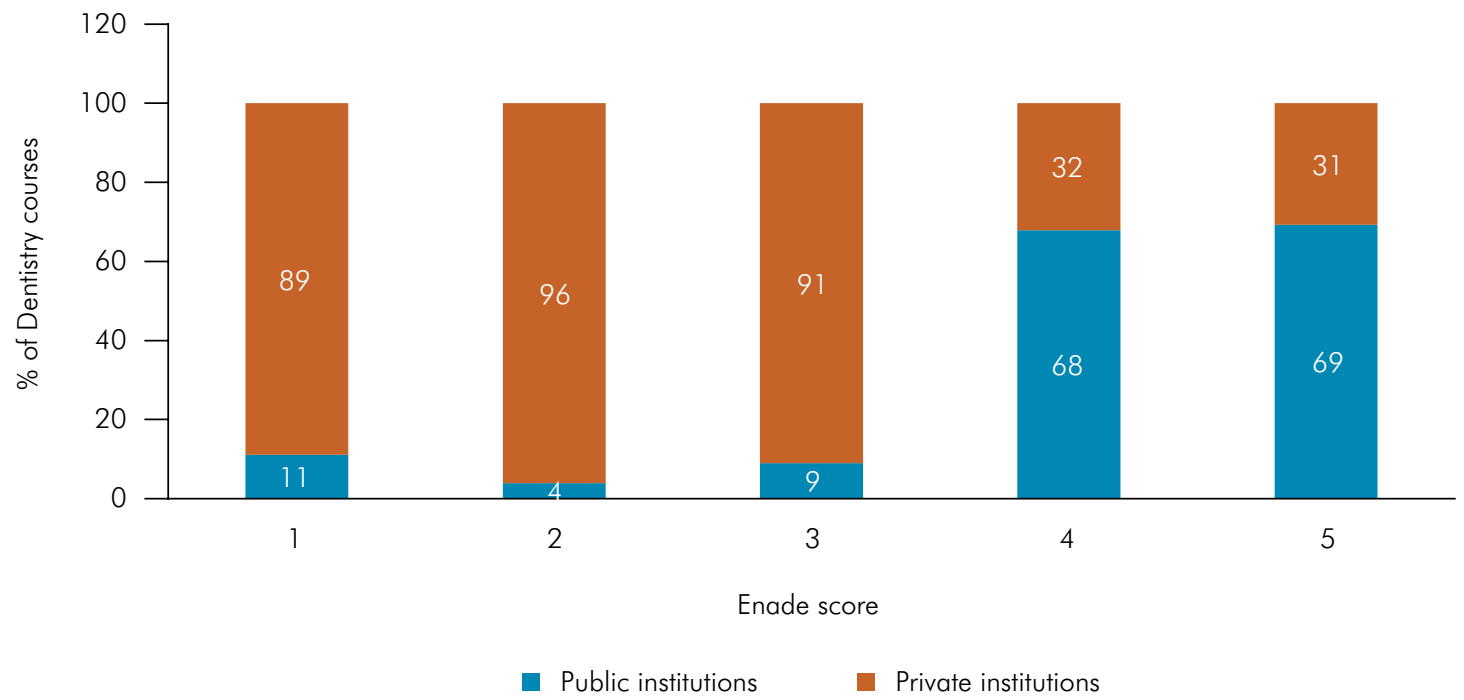

Figure 5. Relative distribution of Enade scores for Dentistry according to the juridical nature of Dentistry courses, obtained from 2016 INEP. ${ }^{12}$ 


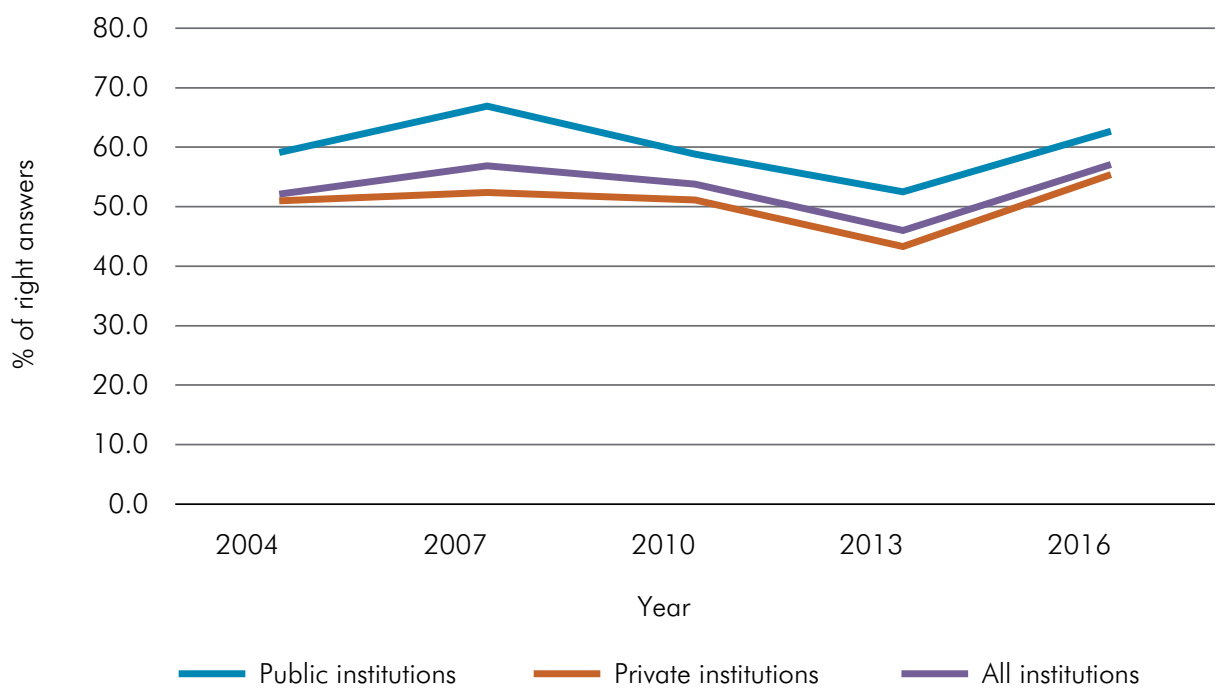

Figure 6. Mean percentage of right answers to the Enade specific assessment of Dentistry in public and private IES, ENADE 2004 to 2016 , obtained from INEP. ${ }^{12}$

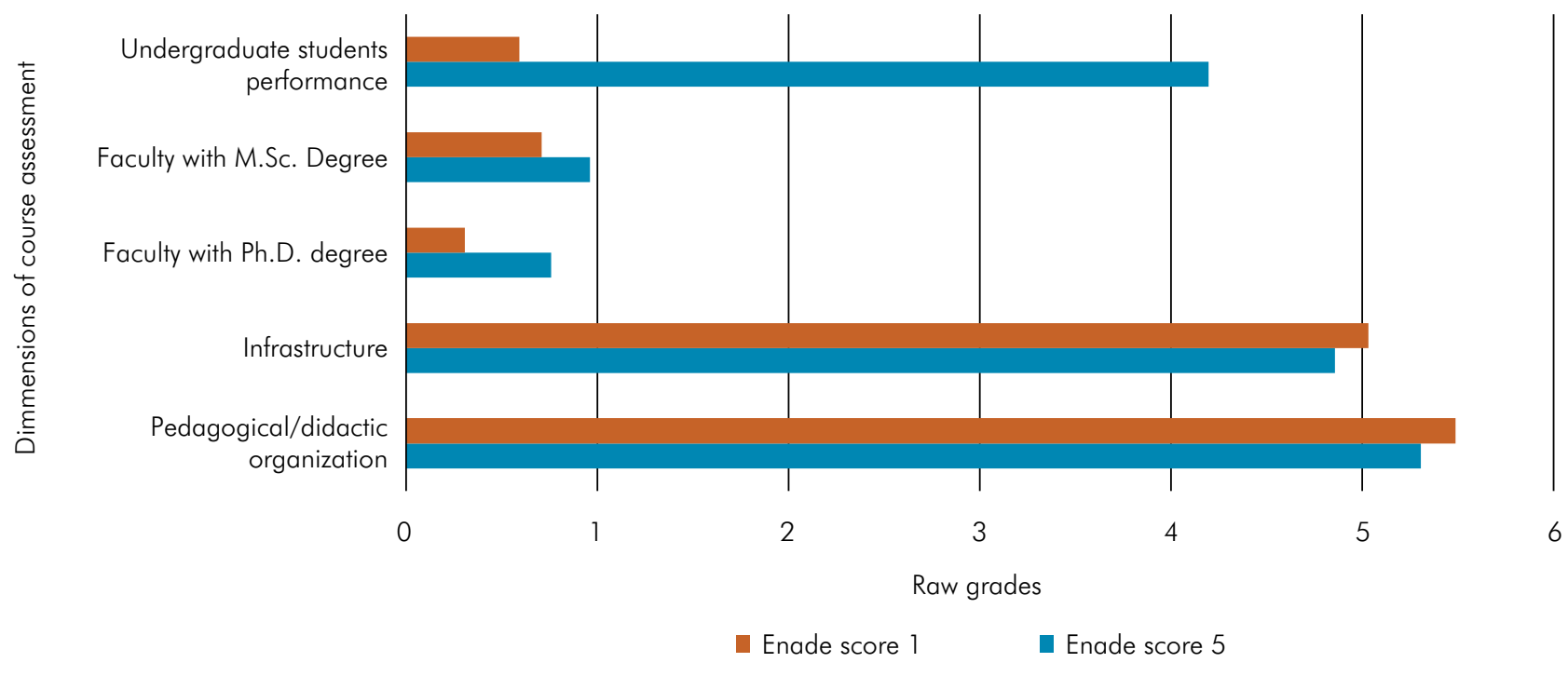

Figure 7. Comparative raw grades of IES with Enade scores 5 and 1 in the different dimensions of course assessment, obtained from 2016 INEP. $^{12}$

raw grades for faculty members with MSc and $\mathrm{PhD}$ degrees among institutions with better outcomes in the 2016 Enade (Figure 7).

The reports of the Technical Board of the National Health Council ${ }^{7}$ from 2018 to 2020 revealed that, among 199 processes analyzed for authorization, recognition, or renewal, $79(40 \%)$ received an unsatisfactory decision report and $110(55 \%)$ received a "satisfactory with recommendations" one. Only 5\% were considered fully satisfactory.

\section{Discussion}

Currently, Brazil is the country with the largest absolute number of Dentistry courses in the world (544), ${ }^{2}$ followed by India (313) ${ }_{1}^{16}$ China (96) ${ }^{17}$ and United States of America (67). ${ }^{18}$ When considering the estimated number of inhabitants for these countries in $2020,{ }^{19}$ the course per habitant ratios are 1:390 thousand, 1:4 million, 1:15 million and 1:4 million, respectively. 
Although the expansion of private education in Brazil has occurred in all fields of knowledge, ${ }^{5}$ the numbers of Dentistry are alarming and should be interpreted based on the context that allowed this expansion.

One of the arguments for this expansion was the clear centralization of education in the richest regions of the country and the insufficient access of Brazilian young adults to higher education. The Brazilian National Education Plans of $2001^{20}$ and $2014^{21}$ highlighted the importance of reducing the regional asymmetries in Brazil. However, this driving force was not efficient in achieving this goal in Dentistry, since the first expansions occurred exactly in places that already concentrated the existing courses. This occurred mainly due to an expansion policy regulated by the private education market, whose objectives have always been the capital return and profit, although partly meeting the demand pointed out by the National Education Plans.

As mentioned in a previous study, ${ }^{22}$ professionals were concentrated in areas with greatest influx of income and in capitals. Similarly, specialists were concentrated in the capitals and within some specialties. The authors also highlighted that the place of graduation was strongly related to the site of practice, since $86 \%$ of dentists were registered in the same state where they graduated.

For example, analysis of Figure 4 reveals that in the Southeast region, which has the largest GDP in Brazil, the ratio of dentist per population varied from 1 per 601 inhabitants in $2008^{22}$ to 1 per 526 inhabitants in 2019. The World Health Organization (WHO) does not provide an international "ideal" dentist/ inhabitant ratio due to the immense diversity of local conditions that can interfere with the results. The ratio should be related to factors from the local labor market (number of jobs) and epidemiological profile of oral diseases, among others.

Based on information from the year 2017, ${ }^{23}$ among the countries that have the largest number of dentists in the world - China $(637,000)$, Brazil $(258,842)$, and India $(251,207)$ - Brazil is the country with the highest proportion of dentists per 10,000 inhabitants (12.454), before China (4.458) and India (1.877).

In Brazil, the current dentist/inhabitant ratio is much lower than the parameter adopted by the
Ministry of Health to calculate the public hiring of dentists for primary care. ${ }^{24}$ The growth in the number of professionals was not accompanied by a similar growth in public dental services, and the imbalance of regional distribution previously reported ${ }^{22}$ was also observed among professionals from public and private sectors. ${ }^{25}$ In this context, this study shows that the expansion of Dentistry courses that occurred in the last three decades did not correct the regional inequalities in the distribution of dentists in Brazil; rather, it produced an opposite and undesirable effect, increasing the concentration of professionals in capitals and in the richest regions of the country.

Another important aspect is that the documents that supported the expansion of seats in Dentistry courses also mention the "expansion with quality".6 This fundamental element should be discussed to understand the context of expansion. The SINAES is a complex system, which involves different players: the internal community of the IES in the self-assessment process, the external assessment conducted by peers from different fields of knowledge, and the assessment of Dentistry professors who receive a training process and apply the instruments of INEP. Additionally, the evaluation of undergraduate students' performance (Enade) complements the indicators of the System.

It should be mentioned that a study on guideline compliance of undergraduate courses in Nursing, Medicine, and Dentistry authorized after the establishment of the National Curriculum Guidelines (DCN) showed that the on-site assessment at the recognition stage revealed a much lower compliance to the DCN than that indicated in the pedagogical projects initially submitted for course creation. ${ }^{15}$

The course assessment is performed by on-site visits of peer evaluators who analyze the Pedagogical Project, Faculty, and Infrastructure at three different moments: at the authorization for operation, at course recognition when 50 to $75 \%$ of the hour load has been completed, and in recognition renewal. The courses are evaluated at the end of a process that weighs scores on a scale of 1 to 5 , in which 1 is unsatisfactory and 5 is very good. ${ }^{26}$ When observing the concepts achieved for course authorization, about $60 \%$ obtain Very Good (5) and Good (4) concepts 
and $40 \%$, a satisfactory concept (3). Considering only authorized and functioning courses $(n=145)$, from 2013 to 2018 , about $2 / 3$ (67\%) obtained concepts 4 or 5 , indicating that the criteria for course authorization are easily exceeded by the institutions.

Conversely, when courses with concepts 3, 4, and 5 assigned by INEP evaluators ${ }^{6}$ are submitted to analysis by the Technical Board of the National Health Council, ${ }^{7}$ of the 199 processes, $40 \%$ received an unsatisfactory score, $55 \%$ satisfactory with recommendations, which means they have issues to be solved, and 10 (5\%) obtained a satisfactory score, showing a clear difference between the SINAES analysis and the analysis from the standpoint of the health system needs. This shows an important noncompliance with the legal precepts that should guide the SINAES, which are presented in the article 200 of the Federal Constitution of $1988^{27}$ that attributes to the Brazilian Public Health System the role of health sciences education organizer.

The results of undergraduate students' performance in the National Assessment are object of great influence in the popular imagination on the alleged quality of education obtained. Despite the great visibility, the utilization of Enade as an indicator of the quality of courses is questionable. Managers of private IES argue that these results should not be directly compared because of the different profile between public and private IES students, since the selection process for admission in public IES assures better prepared undergraduate students. Another pertinent criticism concerns the measure of relative performance rather than the degree of proficiency. Since the scores are comparative between participants, the result does not allow to qualitatively state good or bad concepts, but rather better or worse concepts. Combined to this limitation, the evaluation might be influenced by local factors that are not always related to the education process. It is not uncommon to have surprising results that reflect issues such as boycotts or lack of undergraduate students' commitment with the results, which are not individually published. In the opposite direction, maneuvers were also detected to assure that only the best undergraduate students could take the test, artificially raising the final result of the IES. ${ }^{28}$
The higher percentage of faculty members with MSc and PhD degrees in institutions that obtained better results in ENADE shows the fundamental role played by the faculty in the education of undergraduate students, raising the quality even though infrastructure conditions and pedagogical organization may be comparatively worse.

In 2019, the Lancet Journal published two papers ${ }^{29,30}$ with a broad overview on the evolution of oral health indicators in the world population. The authors show that, despite all the evolution of knowledge and scientific evidence that would be sufficient for prevention of the main oral diseases, their burden, prevalence, and severity remain high, with strong correlation with socioeconomic conditions. The authors emphasize the need to review the oral health care model and the integration between oral and general health to broaden the focus on interprofessional practices and the approach to teamwork, revising the training model with greater orientation to the actual population health needs, public health, and social responsibility.

Brazilian Dentistry has increased its scientific and technological development, with outstanding intellectual production since the $19^{\text {th }}$ century. ${ }^{31,32}$ However, it is at risk of a collapse due to a plethora of dentists in the job market. The significant financial and time investment of undergraduate students and their families to obtain a higher education degree is unjustifiable if this education does not assure professionalization, while thousands of Brazilians do not have access to oral health.

\section{Conclusion}

The marked expansion of Dentistry undergraduate courses in Brazil contributed to worsen the regional asymmetries in the availability of dentists. As a consequence of this disordered growth, there was a reduction in the dentist/inhabitants ratio and increase of relative costs of education, due to the unfilled seats in schools. One-third of authorized dental schools seats are not filled, showing the clear distortion between seat offer and social need, and the necessity of ceasing the offer of new courses. Changes in the National System of Higher Education 


\begin{abstract}
Assessment (SINAES) and its articulation with the Public Health System, effectively leading to quality regulation of courses, are urgent measures that should be advocated in Brazil.
\end{abstract}

\title{
References
}

1. Cunha ES. História da odontologia no Brasil (1500-1900). 2nd ed. Rio de Janeiro: Científica; 1952.

2. Cadastro Nacional de Cursos e Instituições de Educação Superior - e-MEC. Brasília, DF) Instituto de Pesquisas Educacionais Anísio Teixeira; 2020. [cited 2020 Mar 14]. Available from: http://emec.mec.gov.br.

3. Brasil. Lei No 4.024, de 20 de dezembro de 1961. Fixa as Diretrizes e Bases da Educação Nacional. Diário Oficial União, 27 dez 1961.

4. Carvalho ACP, Kriger L. Ensino de Odontologia no Brasil. In: Carvalho ACP, Kriger L. Educação odontológica. São Paulo: Artes Médicas; 2006. p. 5-17.

5. Corbucci PC, Kubota LC, Meira APB. Evolução da educação superior privada no Brasil: da reforma universitária de 1968 à década de 2010. Radar. 2016 Aug; 46:7-12.

6. Brasil. Lei N 10.861, de 14 de abril de 2004. Institui o Sistema Nacional de Avaliação da Educação Superior - SINAES e dá outras providências. Diário Oficial União, 15 abr 2004.

7. Brasil. Decreto $N^{\circ} 9.235$, de 15 de dezembro de 2017. Dispõe sobre o exercício das funções de regulação, supervisão e avaliação das instituições de educação superior e dos cursos superiores de graduação e de pós-graduação no sistema federal de ensino. Diário Oficial União, 18 dez 2017.

8. Conselho Federal de Odontologia - CFO. Profissionais e entidades cadastradas. Brasília, DF: Conselho Federal de Odontologia; 2020.

9. Instituto Brasileiro de Geografia e Estatística - IBGE. Estimativas de população enviadas ao TCU. Rio de Janeiro: Instituto Brasileiro de Geografia e Estatística; 2018 [cited 2020 Mar 14]. Available from: http://www.ibge.gov.br/estatisticas/sociais/populacao/9103estimativas-de-populacao. html? edicao $=22367 \& t=$ resultados

10. Instituto Brasileiro de Geografia e Estatística - IBGE. Brasil/Distrito Federal. Sistema de contas regionais. 2016. Rio de Janeiro: Instituto Brasileiro de Geografia e Estatística; 2016 [cited 2020 Mar 14]. Available from: http://cidades.ibge.gov.br/brasil/df/ pesquisa/10060/60147? ano $=2016$

11. Instituto de Pesquisas Educacionais Anísio Teixeira - INEP. Censo da educação superior. Brasília, DF: Instituto de Pesquisas Educacionais Anísio Teixeira; 2020 [cited 2020 Mar 14]. Available from: http://portal.inep.gov.br/censo-da-educacao-superior.

12. Instituto de Pesquisas Educacionais Anísio Teixeira - INEP. Educação superior. Enade. Resultados. Brasília, DF: Instituto de Pesquisas Educacionais Anísio Teixeira; 2020 [cited 2020 Mar 14]. Available from: http://inep.gov.br/relatorios

13. Instituto de Pesquisas Educacionais Anísio Teixeira - INEP. Educação superior. Indicadores de qualidade: CPC 2016. Brasília, DF: Instituto de Pesquisas Educacionais Anísio Teixeira; 2020 [cited 2020 June 27]. Available from: http://portal.inep.gov.br/educacaosuperior/indicadores-de-qualidade/resultados

14. Ministério da Educação (BR). Programa de Apoio a Planos de Reestruturação e Expansão das Universidades Federais. Brasília: DF: Ministério da Educação; 2007 [cited 2020 Mar 14]. Available from: http://reuni.mec.gov.br/o-que-e-o-reuni.

15. Haddad AE, Laganá D, Assis EQ, Morita MC, Toledo AO, Rode S, et al. A aderência dos cursos de graduação em Odontologia às Diretrizes Curriculares Nacionais. In: Haddad AE, Ristoff D, Passarella TM. A aderência dos cursos de graduação em Enfermagem, Medicina e Odontologia às Diretrizes Curriculares Nacionais. Brasília. DF: Ministério da Saúde e Ministério da Educação; 2006. p. 119-162.

16. Dental Council of India. New Delhi; 2020 [cited 2020 June 27]. Available from: http://dciindia.gov.in/CollegeSearch. aspx? ColName=\&Courseld $=1 \&$ Splld=0\&Stateld=\&Hospital=\&Type=0\&Status=--Select--

17. China's University and College Admission System. Beijing; 2020 [cited 2020 June 27]. Available from: https://www.cucas.cn/ studyinchina/admissions/2019/All_Year_Around/Dentistry/5_5_60.html

18. American Dental Education Association - ADEA. Predoctoral dental education programs (Accredited dental schools). Washington, DC: American Dental Education Association; 2020 [cited 2020 June 27]. Available from: https://www.adea.org/dentalschools/

19. Worldometer.Countries in the world by population (2020). London; 2020 [cited 2020 June 27]. Available from: https://www.worldometers.info/world-population/population-by-country 
20. Brasil. Lei N 10.172, de 9 de janeiro de 2001. Aprova o Plano Nacional de Educação e dá outras providências. Diário Oficial União, 10 jan 2001.

21. Brasil. Lei № 13.005, de 25 de junho de 2014. Aprova o Plano Nacional de Educação e dá outras providências. Diáiro Oficial União, 26 jun 2014.

22. Morita MC, Haddad AE, Araúio ME. Perfil atual e tendências do cirurgião-dentista brasileiro. Maringá: Dental Press, 2010 [cited 2020 Mar 14]. Available from: http://cfo.org.br/ wpcontent/uploads/2010/04/PERFIL_CD_BR_web.pdf.

23. World Health Organization - WHO. Global Health Observatory data repository. Genève: World Health Organization; 2020 [cited 2020 June 27]. Available from: http://apps.who.int/gho/data/node.main.HWFGRP_0060?lang=en

24. Ministério da Saúde (BR). Portaria n 2.436, de 21 de setembro de 2017. Aprova a Política Nacional de Atenção Básica, estabelecendo a revisão de diretrizes para a organização da Atenção Básica, no âmbito do Sistema Único de Saúde (SUS). Diário Oficial União, 21 set. 2017.

25. Cascaes AM, Dotto L, Bomfim RA. Tendências da força de trabalho de cirurgiões-dentistas no Brasil, no período de 2007 a 2014: estudo de séries temporais com dados do Cadastro Nacional de Estabelecimentos de Saúde. Epidemiol Serv Saúde. 2018;27(1):e201723615. http://dx.doi.org/10.5123/s1679-49742018000100015

26. Instituto Nacional de Estudos e Pesquisas Educacionais Anísio Teixeira - INEP. Diretoria de Avaliação da Educação Superior. Instrumento de avaliação de cursos de graduação presencial e a distância: reconhecimento e renovação de reconhecimento. Brasília, DF: Instituto Nacional de Estudos e Pesquisas Educacionais Anísio Teixeira; 2017.

27. Brasil. Senado Federal. Constituição Federal de 1988. Brasília: DF: Senado Federal; 1988

28. Brasil. Ata n 18 de 23 de maio de 2018. Plenário TC 010.471/2017-0. Brasília: DF: Tribunal de Contas da União; 2018 [cited 2020 Mar 14]. Available from: http://www.tcu.gov.br/Consultas/Juris/Docs/CONSES/TCU_ATA_0_N_2018_18.pdf

29. Peres MA, Macpherson LMD, Weyant RJ, Daly B, Venturelli R, Mathur MR, Listl S, Celeste RK, Guarnizo-Herreño CC, Kearns C, Benzian H, Allison P, Watt RG. Oral diseases: a global public health challenge. Lancet. 2019 Jul;394(10194): $249-60$. https://doi.org/10.1016/S0140-6736(19)31146-8

30. Watt RG, Daly B, Allison P, Macpherson LMD, Venturelli R, Listl S, et al. Ending the neglect of global oral health: time for radical action. Lancet. 2019 Jul 20; 394(10194):261-72. https://doi.org/10.1016/S0140-6736(19)31133-X

31. Scimago Journal and Country Rank. Amsterdam: Elsevier; 2020 [cited 2020 Mar 14]. Available from: https://www.scimagojr.com

32. Coordenação de Aperfeiçoamento de Pessoal de Nível Superior - Capes. Relatório da avaliação quadrienal Odontologia 2017 [cited 2020 Mar 14]. Available from: http://capes.gov.br/images/stories/download/avaliacao/relatorios-finais-quadrienal-2017/20122017ODONTOLOGIA-quadrienal.pdf 